\title{
Biodegradation of 2,4 Dichlorophenol by Pleurotus ostreatus DSM 1833
}

\author{
Heloisa Helena Batista da Silva, Andréa Lima dos Santos Schneider, Elisabeth Wisbeck \\ and Sandra Aparecida Furlan* \\ Universidade da Região de Joinville; Campus Universitário s/n; 89201-972; Joinville - SC - Brasil
}

\begin{abstract}
This work aimed to investigate the capacity of Pleurotus ostreatus DSM 1833 to degrade 2,4-dichlorophenol, important pollutant found in the wastewaters of the paper and cellulose industry. Using a factorial design $2^{2}$, the concentrations of glucose and 2,4-dichlorophenol varied between 0 and $10 \mathrm{~g} . L^{-1}$ and 5 and $30 \mathrm{mg} . L^{-1}$, respectively. The best global biodegradation rate was obtained using $30 \mathrm{mg} . \mathrm{L}^{-1}$ of 2,4-dichlorophenol in the absence of glucose. This culture medium was used for scaling up the process, resulting in a global biodegradation rate of $0.47 \mathrm{mg} . L^{-1} . h^{-1}$. A comparative test between an inoculated medium and an abiotic control demonstrated that 54.1\% of 2,4dichlorophenol degradation could be attributed to the presence of P. ostreatus.
\end{abstract}

Key words: biodegradation; 2,4-dichlorophenol; paper and cellulose industry; Pleurotus ostreatus

\section{INTRODUCTION}

The cellulose and paper industry is one of the most important in the world. The largest producers of cellulose and paste in the world are: Canada (27\%), United States (21\%), Sweden (9\%), Brazil (8\%), Chile and Indonesia (4\% each one). Due to the availability of raw materials and the low production costs of cellulose from eucalyptus that contains short fibers, the Brazilian industry is increasing and participates with $50 \%$ of the world production in this market sector (Valença, 1999). This activity uses large volumes of water and generates toxic compounds (Suominen et al., 1999).

The production of paper by the Kraft process is the most widely used for chemical pulping due to the possibility of recovering the chemical products used. The effluents generated in this process contain large amounts of solids in suspension, constituted mainly by polysaccharides and lignocellulosic compounds that are difficult to degrade. The pulp bleaching stage generates the most deleterious compounds to the environment and with higher resistance to biodegradation (Odendahl, 1994). In the bleaching process, usually carried out with chorine, a number of organochlorinated compounds are produced. Some of them are considered highly toxic as dioxins, dichlorophenols, chloroguaiacols and many kinds of chlorolignines fragments (Harris and Elliott, 2000).

The use of fungi able to degrade lignin seems to be a promising method for the treatment of these effluents, especially, white rot fungi that have an extracellular enzymatic system able to tolerate high concentrations of toxic pollutants (Barr and

*Author for correspondence: sfurlan@univille.br 
Aust, 1994; Matheus et al., 2000; Machado et al., 2005). Enzymes such as lignin peroxidase (LiP) and manganese peroxidase $(\mathrm{MnP})$ are produced by these fungi and there are evidences that these enzymes are responsible for the initial fragmentation of lignin (Rodriguez et al., 2004; Tychanowicz et al., 2006). White rot fungi, such as Pleurotus genus, are able to degrade native wood lignin, industrially modified lignin, like the one released in the Kraft process, and high molecular weight lignin released from pulp bleaching (Soares and Durán, 2001). Pleurotus ostreatus is able to metabolize a variety of xenobiotic pollutants such as polychlorinated biphenols, hydrocarbon aromatic policycles, and pesticides (Espósito and Silva, 2004). In many cases, strains of $P$. ostreatus have shown more activity in comparison to other lignolytic fungi to metabolize these compounds (Wu et al., 2005). Many studies envolving fungi of Pleurotus genus in biodegradation of aromatic compounds (Kamida et al., 2005; Novotny et al., 1999; Santos et al., 2000), and chlorophenols specifically (Kubatova et al., 2001; Munari et al., 2003; Pointing, 2001; Rodriguez et al., 2004) have been conducted.

Other lignin degrading basidiomycete, such as Phanerochaete chrysosporium, has been reported in 2,4 diclorophenol degradation using a general pathway for the oxidative degradation of chlorinated aromatic compouds (Valli and Gold, 1991). The objective of this work was to evaluate the ability of Pleurotus ostreatus DSM 1833 to degrade 2,4-dichlorophenol, aiming its further application in the effluent treatment of paper and cellulose industry.

\section{MATERIALS AND METHODS}

\section{Microorganism and maintenance}

Pleurotus ostreatus DSM 1833 strain was obtained from the DSMZ - "Deutsche Sammlung von Mikrorganismen und Zellkulturen Gmbh" and was grown in Petri dishes containing WDA (Wheat Dextrose Agar) medium (1 liter of wheat extract, $20 \mathrm{~g}$ of dextrose and $15 \mathrm{~g}$ of agar) at $4^{\circ} \mathrm{C}$ as defined by Furlan et al. (1997).

\section{Study of Pleurotus ostreatus ability to degrade 2,4-dichlorophenol}

To evaluate $P$. ostreatus ability to degrade $2,4-$ dichlorophenol (2,4-DCP), a basic culture medium composed by wheat extract (Furlan et al., 1997) was used. Different glucose and 2,4-DCP concentrations were investigated using a factorial design $\left(2^{2}\right)$ with a central point (Table 1 ).

Erlenmeyer flasks $(500 \mathrm{ml})$ containing $100 \mathrm{ml}$ of culture medium were inoculated in triplicate, with an agar disk of $15 \mathrm{~mm}$ diameter containing the fungal mycelium. After inoculation, the flasks were incubated at $30^{\circ} \mathrm{C}$ and $120 \mathrm{rpm}$ for 14 days in a Certomat (Braun) shaker. Initial $\mathrm{pH}$ was 6.0 (natural $\mathrm{pH}$ of the medium) and it was not controlled during the process. Samples were taken periodically at $0,1,2,4,8,12$ and 14 days for glucose and 2,4-DCP analyses. Biomass concentration was gravimetrically evaluated at the end of the process.

The factorial design was analysed using the software STATISTICA 6.0, from "Stat Soft".

Table 1 - Factorial design $2^{2}$ of the experiments performed with Pleurotus ostreatus in Erlenmeyer flasks.

\begin{tabular}{ccc}
\hline Variables & \multicolumn{3}{c}{ Levels $^{1}$} \\
\hline [Glucose] & - & + \\
{$[2,4-D C P]$} & 0 & 10 \\
\hline Experiment & 5 & 30 \\
\hline 1 & Glucose $\left(\mathbf{g} . \mathbf{L}^{-1}\right)$ & $\mathbf{2 , 4 - D C P}\left(\mathbf{m g} . \mathbf{L}^{-1}\right)$ \\
\hline 3 & 10 & 30 \\
4 & 10 & 5 \\
Central Point & 0 & 5 \\
& 0 & 17.5 \\
\hline
\end{tabular}

${ }^{1}(+)$ and (-) indicate the level of each variable as inferior and superior, respectively. 


\section{Comparative test between inoculated medium and abiotic control}

To identify the existence of any non-biological degradation of 2,4-DCP, an experiment was performed to compare the degradation of 2,4-DCP in the presence and in the absence of P. ostreatus. The culture medium was composed by wheat extract (Furlan et al., 1997), supplemented with 30 $\mathrm{mg} . \mathrm{L}^{-1}$ of 2,4-DCP. Culture conditions were similar to those described for the previous experiment. The tests were carried out in triplicate for $96 \mathrm{~h}$. The flasks of the abiotic control were not inoculated.

The samples were taken periodically $(0,1,2,12$, $14,24,48,72$ and $96 \mathrm{~h})$ to analyse the concentration of 2,4-dichlorophenol.

\section{Process scaling up}

The experiment was carried out for $112 \mathrm{~h}$ in batch cultivation using a stirred tank bioreactor (B. BRAUN, BIOSTAT B model) of $5 \mathrm{~L}$ with $4 \mathrm{~L}$ working volume.

The initial $\mathrm{pH}$ (6.0) was the natural $\mathrm{pH}$ of the medium. The temperature was kept constant at $30^{\circ} \mathrm{C}$ and the initial $\mathrm{K}_{\mathrm{L}}$ a was adjusted to $27 \mathrm{~h}^{-1}$ (Furlan et al., 2008) by using an airflow equal to 1.0 L. $\mathrm{min}^{-1}$ and an agitation rate of $300 \mathrm{~min}^{-1}$. The culture medium used was composed by wheat extract supplemented by $30 \mathrm{mg} . \mathrm{L}^{-1}$ of 2,4-DCP.

Inoculum was prepared in Erlemmeyer flasks as described previously and inoculation ratio was equal to $10 \%(\mathrm{v} / \mathrm{v})$. Samples of $30 \mathrm{ml}$ from the culture medium were taken periodically to estimate the concentration of 2,4-DCP.

\section{Determination of biomass concentration}

Biomass concentration was periodically evaluated using the gravimetrical method.

\section{Determination of glucose concentration}

The glucose concentration was estimated by high performance liquid chromatography (HPLC, MERCK) with a refraction index detector and a Biorad column AMINEX HPX-87C at $70^{\circ} \mathrm{C}$, eluted with water.

\section{Determination of 2,4-dichlorophenol}

The concentration of 2,4-DCP was estimated by HPLC with an UV detector and a MERCK column LiChrospher model $100 \mathrm{RP} 18$ at $40^{\circ} \mathrm{C}$, eluted with a solution of $65 \%$ sulphuric acid (1.0M) and $35 \%$ acetonitrile.

\section{Statistic analysis}

The data obtained in the experiments related to the factorial design were analysed through the statistical Q test (Rorabacher, 1991) with 95\% confidence level and the Pareto analysis was used to identify and quantify the effect of each factor and their interactions.

For the comparative test between the inoculated medium and the abiotic control, the average values between the replicates and their respective standard deviation were estimated.

\section{Process parameters}

The yield factor of biomass on substrate $(\mathrm{Yx} / \mathrm{s})$ was estimated using the following equations:

$\mathrm{Y}_{\mathrm{X} / \mathrm{S}}=\frac{\mathrm{X}_{\mathrm{f}}-\mathrm{X}_{0}}{\mathrm{~S}_{0}-\mathrm{S}_{\mathrm{f}}} \quad\left(\mathrm{g} \cdot \mathrm{g}^{-1}\right)$

The global rate of 2,4-DCP biodegradation (Vdeg) was estimated for the experiments carried out in Erlenmeyer flasks and in bioreactor.

$\left.\operatorname{Vdeg}=\frac{[2,4 \mathrm{DCP}}{0}\right]-[2,4 \mathrm{DCP}] \quad\left(\mathrm{mg} \cdot \mathrm{L}^{-1} \cdot \mathrm{h}^{-1}\right)$

where:

[2,4DCP $\left.{ }_{0}\right],\left[2,4 \mathrm{DCP}_{\mathrm{f}}\right]-$ initial and final 2,4- DCP concentration (mg. $\left.\mathrm{L}^{-1}\right)$

$\mathrm{S}_{0}, \mathrm{~S}_{\mathrm{f}}$ - initial and final substrate concentration (g. $\mathrm{L}^{-1}$ )

$\mathrm{t}_{\mathrm{f}}$ - process time $(\mathrm{h})$

$\mathrm{X}_{0}, \mathrm{X}_{\mathrm{f}}-$ initial and final biomass concentration $\left(\mathrm{g} . \mathrm{L}^{-1}\right)$

\section{RESULTS AND DISCUSSION}

\section{Study of the ability of $P$. ostreatus to degrade 2,4-dichlorophenol}

The best global rate of 2,4-DCP degradation was obtained in the absence of glucose and in the presence of $30 \mathrm{mg} . \mathrm{L}^{-1}$ of 2,4-DCP in the culture medium (experiment 3) (Table 2). As expected, under these conditions, the cell growth was low due to the absence of glucose in the medium. This suggested that $P$. ostreatus used 2,4-DCP and other nutrients present in the wheat extract as carbon and energy source. This could be interesting for technological application as under these conditions, the mycelium biomass was not generated in large amounts, thus avoiding an undesirable waste. 
Table 2 - Concentrations of glucose, 2,4-DCP and biomass (X) and the respective average global degradation rates for Pleurotus ostreatus cultivation.

\begin{tabular}{ccccc}
\hline Exp & Glucose $\left(\mathbf{g . L} \mathbf{L}^{-1}\right)$ & $\mathbf{2 , 4 - D C P}\left(\mathbf{m g} . \mathbf{L}^{-\mathbf{1}}\right)$ & $\mathbf{X}\left(\mathbf{g . L ^ { - 1 }}\right)$ & $\mathbf{V d e g}\left(\mathbf{m g} \cdot \mathbf{L}^{-1} \cdot \mathbf{h}^{-\mathbf{1}}\right)$ \\
\hline 1 & 10 & 30 & 2.378 & 0.220 \\
2 & 10 & 5 & 3.542 & 0.051 \\
3 & 0 & 30 & 0.199 & 0.423 \\
4 & 0 & 5 & 0.285 & 0.113 \\
5 & 5 & 17.5 & 2.108 & 0.268 \\
\hline
\end{tabular}

As seen in Figure 1, a significant positive effect of initial glucose on final biomass concentration was observed, while Figure 2 showed that the effect of this parameter was negative on the global rate of 2,4-DCP degradation. The positive effect of glucose on Pleurotus growth has also been observed by Furlan et al., (2008), using a culture medium without chlorophenol. The figures also showed that 2,4-DCP presented a significant negative effect on the biomass concentration and a significant positive effect on the global degradation rate. A decrease of about $33 \%$ in the biomass concentration was observed when the chlorophenol concentration was increased from 5 to $30 \mathrm{mg} . \mathrm{L}^{-1}$, and the initial glucose concentration was equal to $10 \mathrm{~g} . \mathrm{L}^{-1}$. The analysis of these results, based solely on biomass concentration suggested a possible inhibition of Pleurotus growth by 2,4DCP, which was contrary to the results reported by Munari et al. (2003) who did not observe any inhibition in $P$. sajor-caju growth in the presence of Kraft effluent, rich in phenols $(225 \mathrm{mg} / \mathrm{L}$ total, 3034 colorimetric units and $\mathrm{pH}$ 5.7).
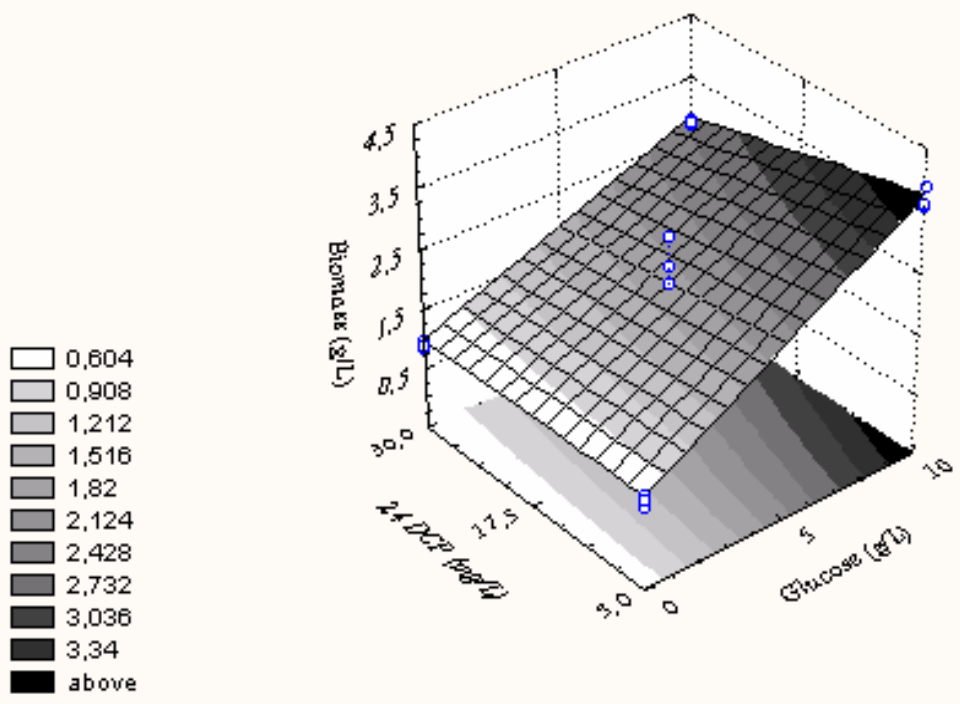

Figure 1 - Effect of 2,4-dichlorophenol and glucose concentration over the microbial growth.

However, when results were analysed based on the yield factors of biomass on substrate $(0.378 \pm$ $0.035 \mathrm{~g} . \mathrm{g}^{-1}$ for the experiment 1 and $0.427 \pm 0.041$ g. $\mathrm{g}^{-1}$ for the experiment 2 ), it suggested a possible negative influence of 2,4- DCP over the glucose consumption and not over the Pleurotus growth. The glucose consumption was higher in test 2
(8.31 g. $\mathrm{L}^{-1}$ ), which presented a higher biomass concentration, higher yield factor of biomass on substrate and lower initial chlorophenol concentration than in test 1 , which presented a substrate consumption equal to 6.33 g.L $\mathrm{L}^{-1}$.

Figure 2 showed that in the range of concentrations studied, the increase of 2,4-DCP 
concentration and the decrease of glucose concentration, promoted the increase of the global degradation rate of 2,4-DCP. Rodriguez et al. (2004) also showed that $P$. pulmonarius and $P$. sajor-caju were able to degrade $16 \mathrm{mg} . \mathrm{L}^{-1}$ of $2,4-$ DCP in 10 and $24 \mathrm{~h}$, respectively, in experiments carried out in Erlenmeyer flasks.
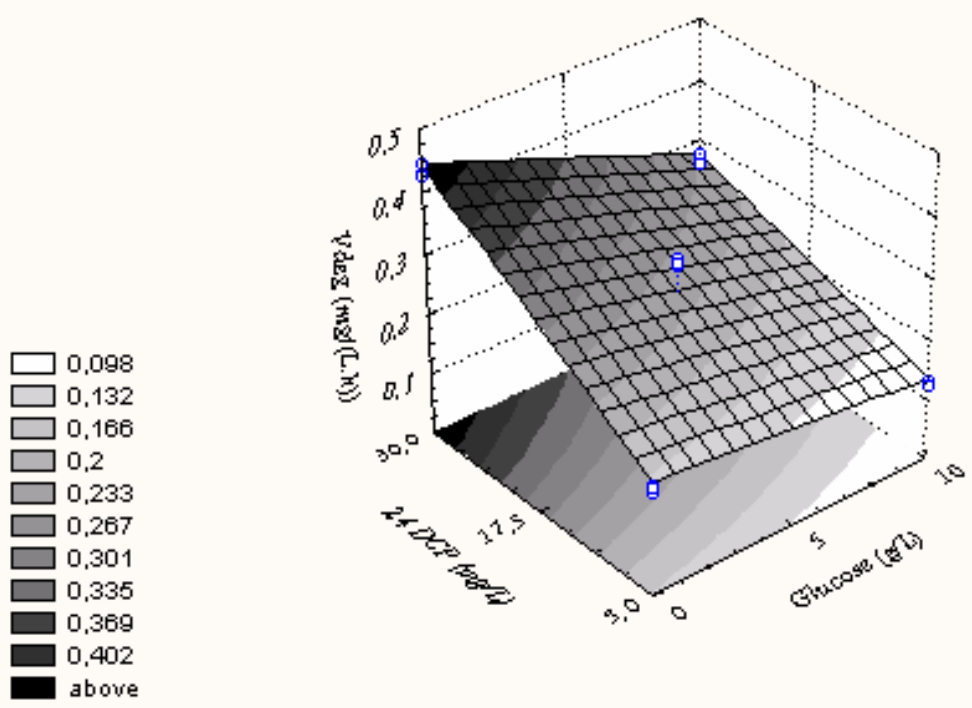

Figure 2 - Effect of 2,4 dichlorophenol and glucose concentration on the global degradation rate.

\section{Comparative test between inoculated medium} and an abiotic control

Although the initial concentration of 2,4-DCP had been $5,17.5$, and $30 \mathrm{mg} \cdot \mathrm{L}^{-1}$, the values measured at the beginning of the processes were (average) about $23 \%$ lower. In order to investigate a possible degradation of 2,4-DCP independent of the fungal metabolism, a comparative test between the inoculated medium with $P$. ostreatus and an abiotic control was performed. The results of this are presented in Figure 3.

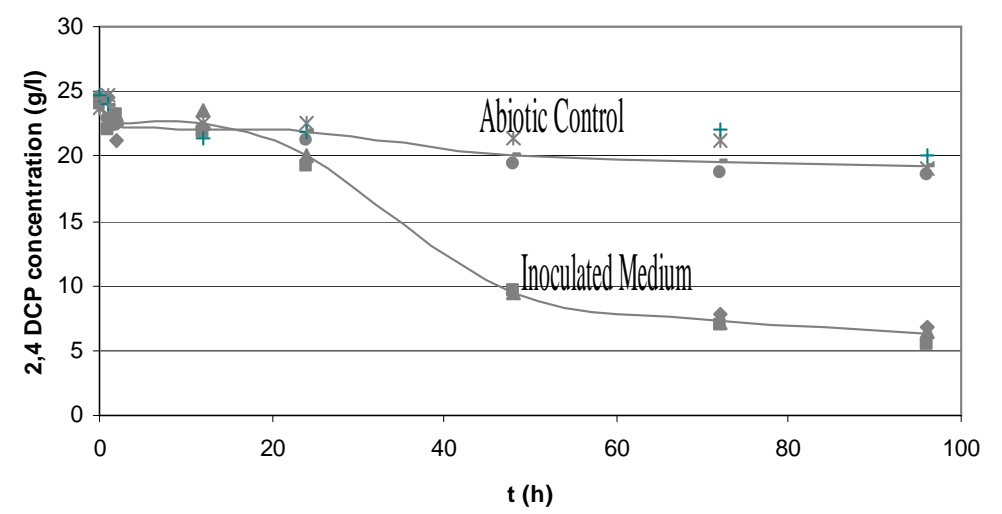

Figure 3 - Profile of 2,4- dichlorophenol degradation in comparative test between inoculated medium and abiotic control. 
A similar behaviour was observed between the culture and the control experiment until $12 \mathrm{~h}$ process. In this period, the concentration of 2,4DCP reduced about $7.2 \%$ in the inoculated medium and $9.3 \%$ in the abiotic control. After this time, higher rate of 2,4-DCP degradation in the inoculated medium was obtained. At the end of the process $(96 \mathrm{~h})$, the reduction of 2,4-DCP concentration (average of replicates) reached $20.2 \%$ in the abiotic control and $74.3 \%$ in the inoculated medium. It meant that $54.1 \%$ of degradation could be attributed to the presence of $P$. ostreatus in the process, confirming its capacity to degrade 2,4-DCP. A similar behaviour was observed by Munari et al. (2003) when P. sajor$c a j u$ was cultivated in Kraft effluent and compared with an abiotic control. A fast drop of total phenols concentration was observed until the $3^{\text {rd }}$ day in both the experiments. The authors suggested that the aeration of the medium could be responsible for the decrease of phenols content. The authors also suggested that this phenomenon could be a result of lacases action, due to their ability to polymerise phenols, reducing the colour of pulp bleaching effluents. However, after 13 days cultivation, the authors attributed $58.9 \%$ phenol degradation to the fungal action.

\section{Process scaling up}

With the objective of establishing the biodegradation kinetic of 2,4-DCP by $P$. ostreatus at large scale, an experiment was conducted in bioreactor. During the cultivation, the medium $\mathrm{pH}$ presented a slight increase from 6.1 to 6.6 in $32 \mathrm{~h}$, time in which 2,4-DCP concentration exhausted (Fig. 4). Once again, the 2,4,6 DCP measured at the beginning of the process was lower than that prepared. This phenomenal should be investigated in further tests.

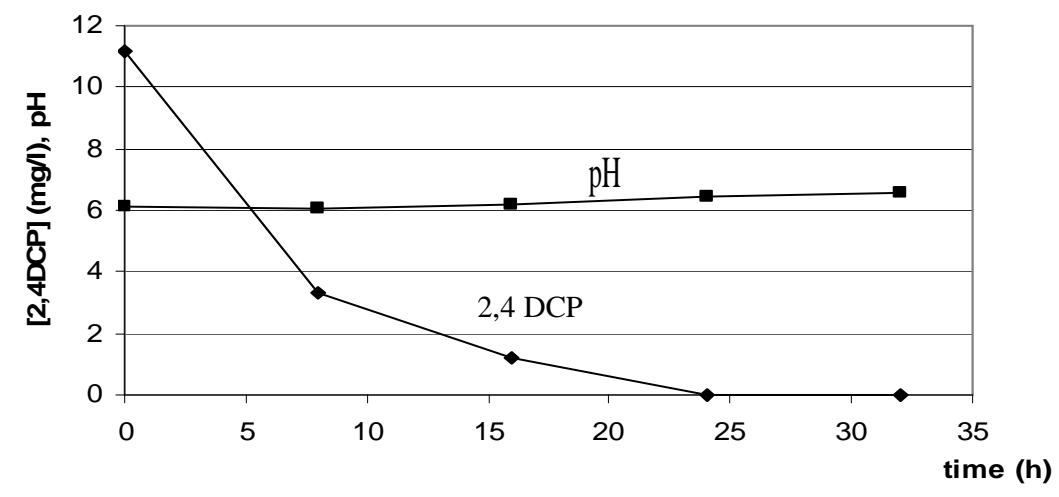

Figure 4 - Profile of 2,4-dichlorophenol degradation by Pleurotus ostreatus and pH evolution with time process for the experiment performed in bioreactor.

Munari et al. (2003) observed a $\mathrm{pH}$ increase from 5.7 to 6.8 in the first days of $P$. sajor-caju cultivation in Kraft effluent in the presence of glucose, with subsequent decrease due to oxalate production. However, in the absence of glucose, no $\mathrm{pH}$ drop was observed. The $\mathrm{pH}$ increased from 5.7 to 6.5 in about 20 days cultivation, which agreed with the results obtained in this work in a shorter time. This difference in time could be attributed to several factors such as different fungal species, different cultivation conditions, different total phenols concentration and different culture media.

\section{CONCLUSIONS}

The increase of initial glucose concentration presented significant negative effect on the global rate of 2,4-dichlorophenol (2,4-DCP) degradation and a positive effect on the biomass concentration of $P$. ostreatus. The increase of 2,4-DCP concentration presented a significant positive effect on its degradation rate and a negative effect on the biomass concentration. Based on the results obtained for the factorial design, the absence of glucose and the presence of 2,4-DCP in the higher level promoted the highest rate of 2,4-DCP 
degradation. Comparing the inoculated medium with $P$. ostreatus and the abiotic control it was observed that in $96 \mathrm{~h}, 54.1 \%$ of 2,4-DCP degradation could be attributed to the presence of $P$. ostreatus, confirming its degradation ability. In bioreactor, the 2,4-DCP concentration reached zero in $24 \mathrm{~h}$ cultivation with a global degradation rate of $0.47 \mathrm{mg} \cdot \mathrm{L}^{-1} \cdot \mathrm{h}^{-1}$. These results confirmed the potential use of $P$. ostreatus in new technologies of paper and cellulose industry effluent treatments. Studies should be carried out using the industrial wastes in order to validate these results.

\section{ACKNOWLEDGMENTS}

The authors thank the scholarship provided by CAPES and the financial support of UNIVILLE.

\section{RESUMO}

A indústria de papel e celulose contribui para a contaminação ambiental devido aos resíduos gerados, especialmente, no processo de branqueamento da polpa Kraft, realizada com cloro. Basideomicetos saprófitas têm a capacidade de degradar compostos organoclorados como cloroligninas e clorofenóis. Este trabalho teve como objetivo investigar a capacidade de Pleurotus ostreatus DSM 1833 em degradar 2,4diclorofenol, importante poluente encontrado nos efluentes da indústria de papel e celulose. Utilizando um planejamento fatorial $2^{2}$, as concentrações de glicose e de 2,4-diclorofenol variaram entre 0 e 10 g. $\mathrm{L}^{-1}$ e 5 e 30 mg.. . $^{-1}$, respectivamente. A melhor taxa global de degradação foi obtida usando-se $30 \mathrm{mg} . \mathrm{L}^{-1}$ de 2,4diclorofenol na ausência de glicose. Este meio de cultura foi utilizado para a ampliação da escala do processo, resultando em uma taxa global de biodegradação de $0,47 \mathrm{mg} \cdot \mathrm{L}^{-1} \cdot \mathrm{h}^{-1}$. Um teste comparativo entre o meio inoculado e o controle abiótico demonstrou que $54,1 \%$ da degradação do 2,4-diclorofenol pode ser atribuída à presença de Pleurotus ostreatus.

\section{REFERENCES}

Barr, D. P. and Aust, S. D. (1994), Mechanisms white rot fungi use to degrade pollutants. Environmental Science \& Technology, 43, 97-106.
Dekker, R. F. H. and Barbosa, A. M. (2001), The effects of aeration and veratryl alcohol on the production of two laccases by the ascomycete Botryosphaeria sp. Enzyme and Microbial Technology, 28, 81-88.

Duran, N. and Espósito, E. (1998), Biodegradação de lignina e tratamento de efluentes por fungos ligninolíticos. In: Melo, I.S., Aevedo, J.L. (eds) Microbiologia Ambiental. Embrapa-CNPMA: Jaguariuna, pp. 269-292.

Furlan, S. A., Virmond, L. J., Miers, D. A., Bonatti, M., Gern, R. M. M. and Jonas, R. (1997), Mushroom strains able to grow at high temperatures and low $\mathrm{pH}$ values. World Journal of Microbioogy and Biotechnology, 13, 689-692.

Furlan, S. A., Gern, R. M. M., Wisbeck, E., Bonatti, M., Silveira M. L. L. and Da Silva, H. H. (2008), Possibilities of Pleurotus applications in food, health and environmental technologies. In: Koutinas, A., Pandey, A., Larroche, C. (eds). Current Topics in Bioprocesses in Food Industry, Asiatech Publishers Inc.: New Delhi, pp. 482-495.

Harris, M. L. and Elliott, J. E. (2000), Reproductive success and chlorinated hydrocarbon contamination in tree swallows (Tachycineta bicolor) nesting along rivers receiving pulp and paper mill effluent discharges. Environmental pollution, 110(2), 307320.

J. Wu, Xio Ya-Zhong and Yu, Han-Qing (2005), Degradation of lignin in pulp mill wastewaters by white-rot fungi on biofilm. Bioresource Technology, 96 (12), 1357-1363.

Kamida, H. M., Durrant, L. R., Monteiro, R. T. R. and Armas, E. D. (2005), Biodegradação de efluente têxtil por Pleurotus sajor-caju. Química Nova, 28(4), 629632.

Kubatova, A., Erbanova, P., Eichlerova, I., Homolka, L., Nerud, F. and Sasek,V. (2001), PCB congener selective biodegradation by the white rot fungus Pleurotus ostreatus in contaminated soil. Chemosphere, 43, 207-215.

Machado, K. M. G., Matheus, D. R., Monteiro, R. T. R. and Bonomi, V. L. R. (2005), Biodegradation of pentachlorophenol by tropical basidiomycetes in soils contaminated with industrial residues. World Journal of Microbiology and Biotechnology, 21: (3), 297301.

Matheus, D. R., Machado, K. M. G. and Bonomi, V. L. R. (2000), Biodegradation of hexachlorobenzene by basidiomycetres in soil contaminated with industrial residuals. World Journal of Microbiology and Biotechnology, 16, 415-421.

Munari, F., Gaio, T. A. and Dillon, A. J. P. (2003), Cinética da secreção de lacases e peroxidases e degradação de fenóis totais em cultivo submerso de Pleurotus sajor-caju com efluentes da indústria papeleira. Paper presented at XIV SINAFERM, Florianópolis, Brazil. 
Novotny, C., Erbanová, P., Sasek, V., Kubatová, A., Cajthmal, T., Lang, E., Krahl, J. and Zadrazil, F. (1999), Extracellular oxidative enzyme production and PAH removal in soil by exploratory mycelium of white-rot fungi. Biodegradation, 10, 159-168.

Odendahl, S. (1994), Environmental protection and consumer demands: a review of trends and impacts. Pulp and Paper Canada, 95, 97-105.

Pointing, S. B. (2001), Feasibility of bioremediation by white rot fungi. Appied Microbiology and Biotechnology, 57, 20-23.

Rodriguez, E., Nuero, O., Guillén, F., Martinez, A. T. and Martinez, M.J. (2004), Degradation of phenolic and non-phenolic aromatic pollutants by four Pleurotus species: The role of laccase and versatile peroxidase. Soil Biology \& Biochemistry, 10, 212217.

Rorabacher, D. (1991), Statistical Treatment for rejection of deviant values: critical values of Dixon's "Q" parameter and related sub range ratios at the 95\% confidence level. Analytical Chemistry, 63, 63-69.

Santos, A.Z., Tavares, C.R.G. and Gomes-da-Costa, S.M. (2002), Treatment of the effluent from kraft bleach plant with the white-rot fungus Pleurotus ostreatoroseus Sing. Brazilian Journal of Chemical Engineering, 19 (4), 371-375.

Silva, M. and Espósito, E. (2004), O papel dos fungos na recuperação ambiental. In: Fungos: uma introdução à biologia, bioquímica e biotecnologia. Caxias do Sul: EDUCS .

Soares, C. H. and Durán, N. (2001), Biodegradation of chlorolignin and lignin-like compounds contained in
E1- pulp bleaching effluent by fungal treatment. Applied Biochemistry and Biotechnology, 95, 135149.

Suominen, K. P., Wittmann, C., Liukkonen, M., Kahkonen, M. A. and Salkinoja-Salonen, M. S. (1999), Ecotoxicological assessment of a recipient lake sediment of bleached-kraft pulping discharges. Enviromental Toxical Chemistry, 18 (10), 2262-2267.

Tinoco, R.; Pickard, M. A. and Vazquez-Duhalt, R. (2001), Kinetic differences of purified laccases from six Pleurotus ostreatus strains. Letters in Applied Microbiology, 32(5), 331-335.

Tychanowicz, G. K., Souza, D. F., Souza, C. G. M., Kadowaki, M. K., Peralta, R. M. (2006), Copper improve the production of laccase by the white-rot fungus Pleurotus pulmonarius in solid state fermentation. Brazilian Archives of Biology and Technology, 49 (5), 699-704.

Valença, A. C. V. (1999), Produtos Florestais. BNDES - FINAME - DNDESPAR. Ed. GESIS/AO2.

Valli, K. and Gold, M. (1991), Degradation of 2,4 dichlorophenol by the lignin-degrading fungus Phanerochaete chrysosporium. Journal of Bacteriology, 173 (1), 345-352.

Received: August15, 2006; Revised: April 15, 2008; Accepted: March 27, 2009. 